\title{
Perceptions of Elementary School Students: Experiences and Dreams about the Life Studies Course
}

\author{
Z. Nurdan Baysal ${ }^{1}$, Özlem Apak Tezcan ${ }^{2, *}$, Kamil Ersin Araç ${ }^{1,3}$ \\ ${ }^{1}$ Department of Primary, Marmara University, İstanbul, Turkey \\ ${ }^{2}$ Department of Primary, Kocaeli University, Kocaeli, Turkey \\ ${ }^{3}$ College of Doğa, Tuzla, İstanbul, Turkey
}

Copyright $(2018$ by authors, all rights reserved. Authors agree that this article remains permanently open access under the terms of the Creative Commons Attribution License 4.0 International License

\begin{abstract}
This study seeks to identify elementary school students' views and perceptions of the Life Studies course through verbal and visual instruments. It employs a descriptive phenomenological research design. The study surveyed second- and third-grade students attending one private elementary school and two state elementary schools. The data was collected using a form including open-ended questions prepared by the researchers. The same form asked students to draw a picture of what kind of setting/class they envisioned for the Life Studies course. As part of the study, which incorporated feedback from 146 students, pictures were examined, and semi-structured interviews were conducted with 14 students selected through criterion sampling. The data collected from both the open-ended questions and the pictures and interviews was analyzed using content analysis. According to the research results, the students considered Life Studies a fun course that teaches and facilitates life skills and provides new information; however, they also reported that Life Studies was a boring course because it requires too much writing and they do not like some activities.
\end{abstract}

Keywords Elementary School, Life Studies, Student Perceptions, Phenomenology, Student Paintings

\section{Introduction}

It is of great importance in our age that children are educated during their elementary school years as individuals who are able to build successful relationships within their environment and develop strong life skills. In this regard, the Life Studies course plays an important role, as it is one of the first courses to achieve this goal (Acar [1]; Aykaç [2]; Belet [3]; Binbaşığlu [4]; Köken [5]; Öztürk [6]). It is also distinguishable from other courses in that it is designed based on a multidisciplinary approach. Especially during early childhood, children perceive life as a whole, and there is usually no individual situation or event for them. Thus, lessons are not divided into social studies and science in elementary education; the Life Studies course is included in the education system as a combination of art, contemporary ideas, and values (Sönmez [7]). The objective of the Life Studies course is to educate individuals to develop basic living skills and live a healthy and safe life, to internalize the values of their society, to be self-aware and sensitive to nature and the environment, and to learn about, support and love their country (Ministry of National Education [8]). Consistent with these aims, it is possible to acquire knowledge, skills, and values in a physical environment suitable to children's emotional development and in a true-to-life structure using practical methods. This is because values have a more important function than knowledge in societies composed of individuals who feel competent and happy in their lives (Demir [9]).

In elementary education, school is, of course, the primary place in which children most effectively enjoy social experiences (Buchanan-Barrow [10]). The Life Studies course makes a major contribution to the satisfaction of curiosity in elementary school students, which is derived from exploring and learning together with peers and adults. In view of the fact that children take their first step toward learning about society and nature on this path of exploration, it is of the utmost importance to select the most appropriate method based on a multidimensional perspective ranging from concrete to abstract, from simplicity to complexity, and from near to far (Bektaş [11]; Güngördü [12]). Accordingly, it is inevitable that the natural and social environment is included in the educational process in order to help children recognize and explore their environment.

The Life Studies course primarily reflects a source of the biological, psychological and social reality of a child (Güçlü [13]). To understand the social development of children, it is essential to make systematic and planned observations and examinations and to learn about their 
physical development, basic needs, behaviors, and skills (Güngördü [12]. For this purpose, any kind of material can be used in class to help children learn more effectively and easily, because teaching materials used in classes have the power to ensure that abstract knowledge in students' minds becomes concrete and permanent. Therefore, the right teaching material should be chosen in the right place at the right time, and students' developmental characteristics and the structure of the subject should be taken into account (Güven [14]; Yel [15]). Accordingly, proper attention to the selection of teaching materials for the Life Studies course requires the abandonment of an approach based only on textbooks. This course should be equipped with a variety of true-to-life methods, such as cluster activities, role-playing, and games (Demir [9]).

Every person longs to acquire the skills that facilitate success and happiness (Yüksel [16]). The effect of teachers, parents, and the social circle in the acquisition of these skills cannot be denied. Life Studies is also a course of trips, observations, life lessons, and experiments. Thus, the natural and social environment of a child should be examined as much as possible. These examinations should follow a true-to-life approach through activities such as intentional visits, observations, and visits to institutions and people. In this regard, the cooperation of family, teachers and students should be ensured, and the internalization of topics after every examination should be promoted through discussion (Güçlü [13]; Güven [14]; Yel [15]).

Many extant studies emphasize that students' opinions and thoughts are much more objective and accurate. For example, painting not only helps children to reflect on their own learning and perception through pictures, but also allows teachers to reflect on teaching through visual elements.

This study seeks to elucidate the importance of the Life Studies course, which prepares children for social life through true-to-life examples. Accordingly, this study attempts to learn about the opinions, experiences, and dreams of students as the "subjects" of the Life Studies course, so that the course can be adapted to students' expectations and demands, and students' positive attitudes toward the course can be fostered. This study is also expected to make significant contributions to the literature, because it employs actual students and collects data using qualitative data collection tools.

\subsection{Problem Statement}

The problem statement of this study is: "What are students' views about the Life Studies course?"

Consistent with the problem statement, the study seeks to answer the following questions:

1. What are the most enjoyable aspects of the Life Studies course?

2. What are the most boring aspects of the Life Studies course?
3. What are the most commonly used instruments in the Life Studies course?

4. What are students' experiences with the Life Studies course?

5. What are students' dreams about the type of setting they envision for the Life Studies course?

\section{Materials and Methods}

\subsection{Research Model}

This study adopted a descriptive phenomenological approach that represents a form of qualitative research design. Descriptive phenomenology assumes an epistemological point of view and focuses on what individuals know (Ersoy [17]). The primary objective of this approach can be expressed as "depicting the perceptions and experiences of participants." This study used multiple data collection tools and also asked children to express their feelings through pictures. Drawing pictures helps children to express themselves when verbal expression is inadequate (Halmatov [18]; Malchiodi [19]). For the analysis of children's pictures, the phenomenological approach primarily requires being open to different meanings, the context of the picture, and the worldview of the child who created it (Malchiodi [19]). The study analyzed students' pictures of setting and space perceptions in conjunction with their written opinions and remarks in semi-structured interviews about their pictures.

\subsection{The Study Group}

In phenomenological studies, the study group should be composed of participants who have experiences in the subject matter of the research and can reflect those experiences (Creswell [20]; Yıldırım \& Şimşek [21]). Thus, this study was conducted in three elementary schools, one of which was a private school, and two of which were state schools, during the spring term of the 2016-2017 academic year. In selecting the schools, the study took into consideration their different socio-economic structures as well as their "ordinary" status, which reflect reality. The study surveyed 476 2nd- and 3rd-grade students attending these schools. The forms of the students who left questions unanswered, evaluated a different course, or experienced difficulty with reading comprehension were deemed invalid and removed. As a result, the analyses were conducted based upon a total sample of 146 student products. The study sample was determined using criterion sampling among purposeful sampling methods. Purposeful sampling allows for a deeper examination of "information-rich cases" (Patton [22]). The criterion sampling method analyzes all situations that meet a predetermined set of criteria. Such criteria can be established by the researcher(s); alternatively, a previously 
prepared list of criteria can be employed (Yıldırım \& Şimşek [21]). In this study, the criteria were determined by the researchers as follows: the selection of schools from different districts; surveys of $2^{\text {nd }}$ - and $3^{\text {rd }}$-grade students on the basis of the fact that $1^{\text {st }}$ graders have difficulty expressing themselves; the selection of research sites in one private school and two states schools to reflect different types of schools; and surveys of students in the classrooms of teachers who volunteered to participate. Table 1 shows the demographic data of the study group.

Table 1. Demographic Data of the Study Group

\begin{tabular}{|c|c|c|}
\hline & f & \% \\
\hline Sex & & \\
\hline Girl & 86 & 58.9 \\
\hline Boy & 60 & 41.1 \\
\hline Type of School & & \\
\hline State School & 87 & 59.6 \\
\hline Private School & 59 & 40.4 \\
\hline Grade & & \\
\hline $2^{\text {nd }}$ grade & 62 & 42.5 \\
\hline $3^{\text {rd }}$ grade & 84 & 57.5 \\
\hline Total & $\mathbf{1 4 6}$ & $\mathbf{1 0 0}$ \\
\hline
\end{tabular}

Given the demographics in Table 1, the study group appears to possess the majority and diversity necessary to reflect the existing case. According to Gardner (1980), researchers who extensively examine the artistic development of children often refer to this period as the "golden age of painting" (schematic stage, 7-9 years), noting that children are not very creative and are timid in this period (as cited in Malchiodi [19]). The greatest achievement at the age of 7-9 is that there is a certain order in spatial relations (Yavuzer [23]). In this regard, the study group appears to be appropriate.

\subsection{Data Collection Process}

The data was collected between February 13-16, 2017, in the spring term of the 2016-2017 academic year. The study first identified classes that satisfied the study criteria and then surveyed students who volunteered to participate in the research. The researchers received the necessary permits and approvals from school directors, teachers, parents, and students. The researchers also received approval from parents and students and secured permissions to publish their written documents, paintings, and research results without revealing students' names.

First, a form consisting of four open-ended questions was prepared by the researchers. This form was limited to four questions by examining previous studies and scales concerning "Student Attitudes towards the Life Studies Course" and considering the cognitive and affective characteristics of the study group. The form was presented to three classroom teachers and two faculty members for review (experts in the field of Life Studies and Social Sciences). This form asks students to write down the most enjoyable and the most boring aspects of the Life Studies course, to describe the most widely used methods and techniques in the class, and to share their experiences. The back page of the form includes the following question: "What kind of setting do you want to do the Life Studies course?" It also asks students to draw a picture of the most desirable setting. The researchers analyzed the available forms and pictures. Accordingly, they selected 14 students to carry out semi-structured interviews and asked them to express themselves, as well as what they intended to express in their pictures.

\subsection{Data Analysis and Interpretation}

The research data was analyzed in several ways. The data gathered from the form of four open-ended questions was analyzed using categorical data analysis, which is a form of content analysis. The categorical data analysis pursued the following processes: (a) data coding, (b) identification of themes (categorization), (c) organization of themes, and (d) production and interpretation of results (Corbin \& Strauss [24]). The questions were coded by two researchers, and the codes were compared and tested for reliability. The analyzed data was digitized and presented in terms of frequency and percentage.

The analysis of the pictures drawn by students was based on the evaluation of visual elements drawn; no psychological assessment was made. The pictures were examined by two different researchers and were categorized into two separate themes:

1. Place/space [outdoor space (garden, nature, tree house, etc.) and indoor space (school, class, etc.)]

2. Seating arrangement [individual seating arrangement (one student per desk, standing, etc.) and group seating arrangement (two students per desk, U-shape, etc.)]

In the analysis of students' pictures, the categories not drawn were coded as "not drawn," and the drawings that could not be evaluated within the specified categories were listed under the other heading. Frequencies and percentages were used in the evaluation and interpretation of the data. One of the biggest challenges concerning students' pictures is the researchers' interpretations of pictures from the perspective of their own adult world. Because many different elements and experiences are combined in children's pictures, it is very difficult to explain and interpret them (Malchioldi [19]). In order to overcome such challenges, it is essential to carry out individual interviews with individual students who have drawn the pictures under study to allow them to express their own unique perspectives (Leonard [25]). In this regard, the study analyzed the interviews conducted with 14 students chosen by the researchers using criterion sampling. The study compared the data obtained by using 
different data collection tools in an attempt to increase the validity and the reliability of the research.

\section{Conclusions}

The research results were categorized into five themes, including "the most enjoyable aspects of the Life Studies course," "the most boring aspects of the Life Studies course," "the most commonly used materials in the Life Studies course," "positive and negative experiences with the Life Studies course," "the place and space in which students want to experience the Life Studies course," and "dreams about the seating arrangement in the Life Studies course."

\subsection{Results of Students' Views about the Most Enjoyable Aspects of the Life Studies Course}

In order to obtain students' positive views about the Life Studies course, participants were asked: "Can you write down your favorite aspects of the Life Studies course into the sun?" Students' written remarks were categorized into five themes, including "meaning attributed to the course," "activities used in the class,", "materials used in the class," "course setting," and "course evaluation." The relevant frequency and percentage values are provided in Table 2.

Table 2. Results of Students' Perceptions of the Most Enjoyable Aspects of the Life Studies Course

\begin{tabular}{|c|c|c|c|}
\hline Themes & Code & f & $\%$ \\
\hline \multirow{8}{*}{ Meaning attributed to the course } & lesson telling our life & 21 & 8.6 \\
\hline & learning new things & 10 & 4.2 \\
\hline & an enjoyable lesson & 8 & 3.2 \\
\hline & an easy lesson & 8 & 3.2 \\
\hline & providing experiences & 7 & 2.8 \\
\hline & talking about a topic & 5 & 2.1 \\
\hline & teaching our values & 4 & 1.6 \\
\hline & a hands-on lesson & 2 & 0.8 \\
\hline \multirow{12}{*}{ Activities used in the class } & reading & 25 & 10.2 \\
\hline & painting & 20 & 8.2 \\
\hline & writing & 16 & 6.5 \\
\hline & talking over examples & 13 & 5.3 \\
\hline & telling a story & 8 & 3.2 \\
\hline & drama & 8 & 3.2 \\
\hline & solving problems & 7 & 2.8 \\
\hline & playing games & 3 & 1.2 \\
\hline & watching videos & 2 & 0.8 \\
\hline & playing charades & 2 & 0.8 \\
\hline & exploration/research & 2 & 0.8 \\
\hline & doing experiments & 1 & 0.4 \\
\hline \multirow{5}{*}{ Materials used in the class } & interpreting images & 8 & 3.2 \\
\hline & enjoying the textbook & 5 & 2.1 \\
\hline & using a smart board & 2 & 0.8 \\
\hline & enjoying the workbook & 2 & 0.8 \\
\hline & enjoying the in-class use of computers to teach & 1 & 0.4 \\
\hline \multirow{3}{*}{ Course setting } & teacher preparing different activities & 5 & 2.1 \\
\hline & going out to schoolyard & 3 & 1.2 \\
\hline & teacher making jokes & 2 & 0.8 \\
\hline \multirow{5}{*}{ Course evaluation } & nice activities & 34 & 13.9 \\
\hline & hanging our works on the board & 4 & 1.6 \\
\hline & easy to get high grades & 3 & 1.2 \\
\hline & enjoying unit evaluation questions & 3 & 1.2 \\
\hline & no exam & 2 & 0.8 \\
\hline \multicolumn{2}{|r|}{ Total } & 246 & 100 \\
\hline
\end{tabular}


In reviewing Table 2, student perceptions of the Life Studies course were centered on the themes "meaning attributed to the course" and "activities used in the class." Students especially enjoy reading, writing and painting. Considering the meanings attributed to the course, students consider Life Studies an enjoyable and easy lesson that explains life and also teaches new information.

\subsection{Results of Students' Views about the Most Boring Aspects of the Life Studies Course}

In order to obtain students' negative views about the Life Studies course, participants were asked: "Can you write down the most boring aspects of the Life Studies course?"
According to their written remarks, participants' responses were categorized into four themes, including "meaning attributed to the course," "problems arising from the teacher," "materials used in the class," and "course setting." The relevant frequency and percentage values are provided in Table 3 .

As seen in Table 3, negative perceptions of the Life Studies course stem primarily from teachers and materials employed. With respect to the Life Studies course, student dislikes include a lot of writing, being unable to take a turn to talk, teachers keeping them waiting, and teachers giving clues. They also do not like course activities and reading stories. They find the course boring because it is easy.

Table 3. Results of Students' Perceptions of the Most Boring Aspects of the Life Studies Course

\begin{tabular}{|c|c|c|c|}
\hline Themes & Code & f & $\%$ \\
\hline \multirow{3}{*}{ Meaning attributed to the course } & a boring course & 12 & 10.7 \\
\hline & finding the course boring because of its very easy nature & 9 & 8.0 \\
\hline & finding the course boring because of being unable to understand the subject & 2 & 1.8 \\
\hline \multirow{9}{*}{ Problems arising from the teacher } & a lot of writing & 26 & 23.1 \\
\hline & unable to talk in the class (unable to take a turn) & 9 & 8.0 \\
\hline & teacher keeps students waiting & 4 & 3.6 \\
\hline & reading the same text twice & 4 & 3.6 \\
\hline & teacher gives clues & 3 & 2.7 \\
\hline & silent reading & 3 & 2.7 \\
\hline & difficulty of exams & 1 & 0.9 \\
\hline & teacher putting a mark on student notebook & 1 & 0.9 \\
\hline & preparing summaries & 1 & 0.9 \\
\hline \multirow{5}{*}{ Materials used in the class } & reading stories & 6 & 5.3 \\
\hline & questions in the textbook & 4 & 3.6 \\
\hline & reading from a photocopy & 3 & 2.7 \\
\hline & reading text from the textbook & 3 & 2.7 \\
\hline & studying using a computer & 2 & 1.8 \\
\hline \multirow{3}{*}{ Course setting } & dislike activities & 14 & 12.5 \\
\hline & friends prevented listening to the course & 3 & 2.7 \\
\hline & much noise in class & 2 & 1.8 \\
\hline \multicolumn{2}{|r|}{ Total } & 112 & 100 \\
\hline
\end{tabular}

\subsection{Results of Students' Views about the Most Commonly Used Materials in the Life Studies Course}

In order to obtain students' experiences and observations about the Life Studies course, participants were asked: "What are the materials your teacher most commonly uses in the Life Studies course? Can you write them down?" The frequency and percentage values concerning students' written expressions are provided in Table 4.

As seen in Table 4, the most commonly used materials in the Life Studies course include a board marker, textbook, board, smart board, computer, projector, and notebook. The least commonly used materials include an earth model, compass, guide book, and a map of Turkey. 
Table 4. Results of Students' Perceptions of the Most Commonly Used Materials in the Life Studies Course

\begin{tabular}{|c|c|c|c|}
\hline & Materials & $f$ & $\%$ \\
\hline 1 & board marker & 81 & 18.7 \\
\hline 2 & textbook & 67 & 15.5 \\
\hline 3 & board & 43 & 10.1 \\
\hline 4 & smart board & 38 & 8.8 \\
\hline 5 & computer & 37 & 8.6 \\
\hline 6 & projector & 30 & 7.1 \\
\hline 7 & book & 23 & 5.3 \\
\hline 8 & board eraser & 19 & 4.4 \\
\hline 9 & activity book & 19 & 4.4 \\
\hline 10 & picture & 11 & 2.5 \\
\hline 11 & human body model & 11 & 2.5 \\
\hline 12 & cardboard & 8 & 1.8 \\
\hline 13 & colorful pencils & 6 & 1.4 \\
\hline 14 & scissors & 6 & 1.4 \\
\hline 15 & printer & 5 & 1.2 \\
\hline 16 & reading book & 4 & 0.9 \\
\hline 17 & photocopy & 4 & 0.9 \\
\hline 18 & telephone & 4 & 0.9 \\
\hline 19 & adhesive & 3 & 0.7 \\
\hline 20 & ruler & 3 & 0.7 \\
\hline 21 & music & 3 & 0.7 \\
\hline 22 & Map of Turkey & 2 & 0.5 \\
\hline 23 & guidebook & 2 & 0.5 \\
\hline 24 & compass & 1 & 0.2 \\
\hline 25 & earth model & 1 & 0.2 \\
\hline \multicolumn{2}{|r|}{ Total } & 432 & 100 \\
\hline
\end{tabular}

\subsection{Results of Students' Experiences with the Life Studies Course}

In order to learn about students' experiences and observations relating to the Life Studies course, participants were asked: "Can you share with us what you experienced in an unforgettable Life Studies course?" According to students' written explanations, student experiences are divided into the categories of positive and negative experiences by the researchers. The frequency and percentage values concerning students' positive experiences are provided in Table 5.

Table 5. Results of Positive Student Experiences in the Life Studies Course

\begin{tabular}{|c|c|c|c|c|}
\hline & Theme & Code & $f$ & $\%$ \\
\hline \multirow{18}{*}{ Positive Experiences } & \multirow{3}{*}{ Active participation in the class } & taking a turn to talk & 11 & 15.5 \\
\hline & & making a model & 8 & 11.3 \\
\hline & & conducting self-assessment & 2 & 2.9 \\
\hline & \multirow{11}{*}{ Having an enjoyable time in the class } & playing games & 9 & 12.6 \\
\hline & & drawing pictures & 8 & 11.3 \\
\hline & & teacher making jokes & 5 & 7.0 \\
\hline & & singing & 5 & 7.0 \\
\hline & & going out to schoolyard & 5 & 7.0 \\
\hline & & learning new things & 4 & 5.6 \\
\hline & & reading funny stories & 4 & 5.6 \\
\hline & & playing charades & 2 & 2.9 \\
\hline & & reading poems & 2 & 2.9 \\
\hline & & doing experiments & 1 & 1.4 \\
\hline & & watching movies & 1 & 1.4 \\
\hline & \multirow[b]{2}{*}{ Enjoying the course content } & using visuals on the computer & 1 & 1.4 \\
\hline & & preparing non-book activities & 1 & 1.4 \\
\hline & \multirow{2}{*}{ Feeling successful } & giving the right answer when raising hand for the first time & 1 & 1.4 \\
\hline & & when teacher likes most of what I do & 1 & 1.4 \\
\hline \multicolumn{3}{|c|}{ Total } & 71 & 100 \\
\hline
\end{tabular}


As seen in Table 5, students' positive experiences with the Life Studies Course are categorized into themes, including "active participation in the class," "having an enjoyable time," "enjoying the course content," and "feeling successful." Considering students' responses, participants enjoy taking a turn to talk and being engaged in an activity on their own. Their positive experiences also include playing games and drawing pictures in the class, and teachers who are good-humored and make jokes.

With respect to the same question, the frequency and percentage values concerning students' negative experiences are provided in Table 6 .

Table 6. Results of Negative Student Experiences in the Life Studies Course

\begin{tabular}{|c|c|c|c|c|}
\hline & Theme & Code & f & $\%$ \\
\hline \multirow{11}{*}{ Negative Experiences } & \multirow{3}{*}{$\begin{array}{l}\text { Remaining passive in } \\
\text { the class }\end{array}$} & teacher speaks all the time & 6 & 17.1 \\
\hline & & unable to take a turn to talk & 3 & 8.7 \\
\hline & & teacher's sex discrimination & 1 & 2.8 \\
\hline & \multirow{3}{*}{$\begin{array}{l}\text { Disliking the course } \\
\text { content }\end{array}$} & reading very funny texts & 2 & 5.7 \\
\hline & & reading sad stories & 2 & 5.7 \\
\hline & & learning that life will not always be lived by playing games & 1 & 2.8 \\
\hline & \multirow{3}{*}{ Feeling unsuccessful } & difficulty in completion because there is a lot of written homework & 11 & 31.4 \\
\hline & & becoming upset about giving the wrong answer & 4 & 11.4 \\
\hline & & not doing an activity well & 1 & 2.8 \\
\hline & \multirow{2}{*}{ Feeling guilty } & displaying unfavorable behaviors in class & 3 & 8.7 \\
\hline & & forgetting to bring notebook & 1 & 2.8 \\
\hline \multicolumn{3}{|r|}{ Total } & 35 & 100 \\
\hline
\end{tabular}

As seen in Table 6, students' negative experiences with the Life Studies Course are categorized into themes, including "remaining passive in the class," "disliking the course content," "feeling unsuccessful," and "feeling guilty." Considering students' negative experiences, participants do not like it when their teacher speaks at all times, and they have difficulty because there is a lot of written homework.

\subsection{Results of Students' Experiences of What Kind of Place They Envision for the Life Studies Course}

In order to learn about students' dreams regarding the Life Studies course, participants were asked: "What kind of place do you want for the Life Studies course? Can you draw a picture of it?" The analysis of students' pictures yielded two categories of themes: "what kind of setting/space do they want for the course" and "what type of seating arrangement do they want to have." The relevant frequency and percentage values are provided in Tables 6 and 7.

\subsection{Results of Students' Perceptions of What Kind of Setting/Space They Envision for the Life Studies Course}

Table 7 shows the frequency and percentage values for the themes and codes determined, based on the analysis of students' pictures, with respect to their perceptions of what kind of setting/space they envision for the Life Studies course.
Table 7. Results of Students' Perceptions of What Kind of Setting/Space They Envision for the Life Studies Course

\begin{tabular}{|c|c|c|c|}
\hline Theme & Code & $f$ & $\%$ \\
\hline \multirow{8}{*}{ Outdoor space } & in nature & 43 & 28.5 \\
\hline & in the schoolyard & 15 & 10 \\
\hline & with animals & 14 & 9.3 \\
\hline & in an orchard & 5 & 3.1 \\
\hline & in a park & 3 & 2.0 \\
\hline & at a beach & 2 & 1.3 \\
\hline & in an arbor & 2 & 1.3 \\
\hline & at a farm & 2 & 1.3 \\
\hline \multirow{16}{*}{ Indoor space } & in the classroom & 17 & 11.2 \\
\hline & in a classroom with colorful balloons & 3 & 2.0 \\
\hline & in a sun-drenched classroom & 2 & 1.3 \\
\hline & in a classroom with musical instruments & 1 & 0.7 \\
\hline & in the school & 11 & 7.3 \\
\hline & in a flying school & 1 & 0.7 \\
\hline & in a private school & 1 & 0.7 \\
\hline & in a safe school & 1 & 0.7 \\
\hline & in a library & 4 & 2.6 \\
\hline & in a tree house & 3 & 2.0 \\
\hline & at home & 2 & 1.3 \\
\hline & in a private course/training center & 2 & 1.3 \\
\hline & in a laboratory/experiment room & 2 & 1.3 \\
\hline & in a silent place & 1 & 0.7 \\
\hline & in a science and arts center & 1 & 0.7 \\
\hline & in my room & 1 & 0.7 \\
\hline Other & in a moving truck & 1 & 0.7 \\
\hline Not drawn & --- & 11 & 7.3 \\
\hline \multicolumn{2}{|r|}{ Total } & 151 & 100 \\
\hline
\end{tabular}

Given the data in Table 7, 86 of the student perceptions 
of a space to study the Life Studies course are included in the group of outdoor space, while 53 are included in the group of indoor space. One statement of student perception that reflects imagination states "on trips in a truck that travels to different countries." Eleven students did not draw a picture of what kind of place they envisioned for the Life Studies course. Considering students' pictures, participants most often want to study in an outdoor space. Even when they prefer an indoor space, they depict the indoor area through drawings such as nature, sun, tree, etc. Student pictures and interviews included in the categories determined by the researchers are as follows: Figure 1 represents the place in which Tuğçe wants to participate in the Life Studies (LS) course, and Figure 2 represents the place in which Derya wants to participate in the LS course.

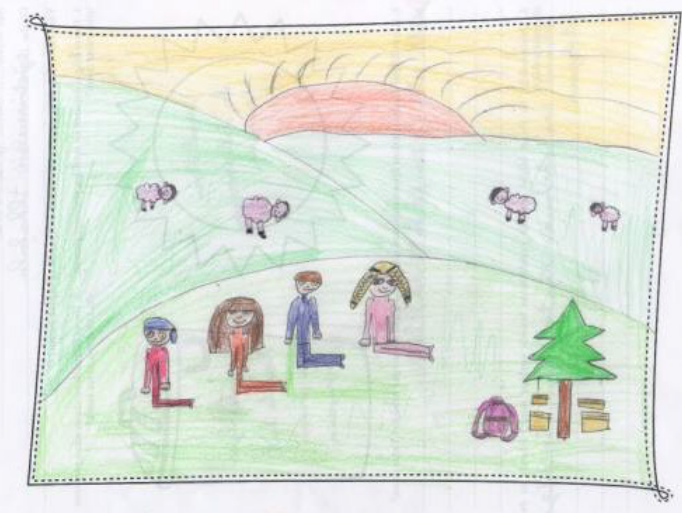

Figure 1. The place in which Tuğce wants to study LS

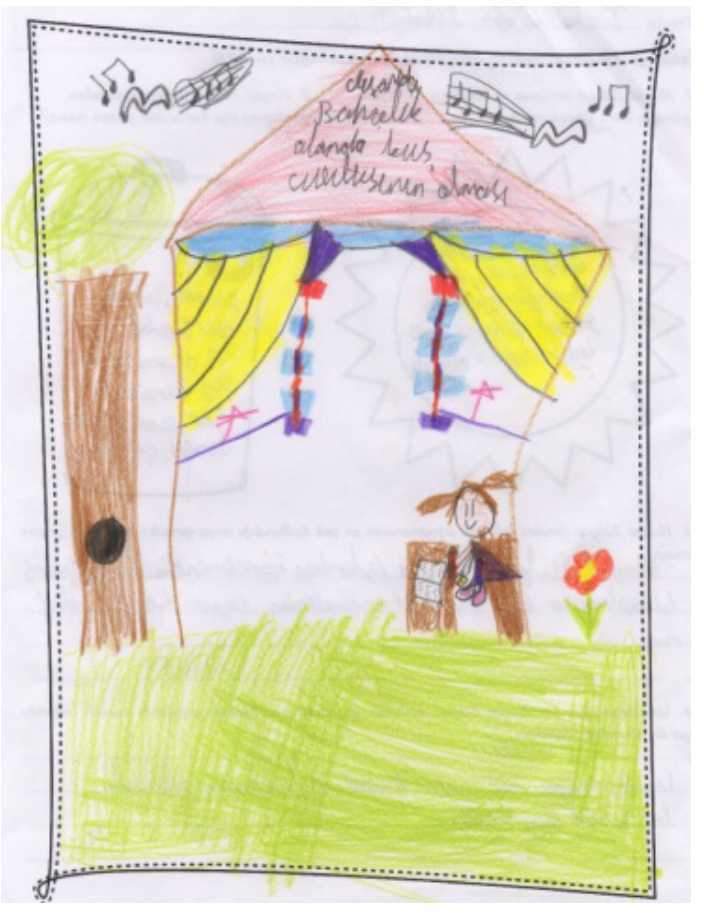

Figure 2. The place in which Derya wants to study LS
In the interview with Tuğce, who drew the picture in Figure 1, she was asked: "You draw a picture of the place in which you want to participate in the Life Studies course. Can you explain your picture?" Tuğce responded as follows: "I would like to do the Life Studies course in a mountainous place, because clean air and a beautiful-smelling atmosphere are better for children. There is nowhere dirty and oil-polluted in this picture. The notebook and bag necessary for the course are also under the tree. So, we can speak about nature's benefits in nature because Life Studies is a lesson to be done in life. We can see the yard only in the physical education class. We always do the Life Studies course in the classroom." Derya's drawing in Figure 2 expressed her views as follows: "The children are studying the Life Studies course in the arbor. I also draw a curtain to prevent the sunlight from coming into the arbor. I also decorated with ribbons. Birds are singing. I would like to study Life Studies in such a bright, cool and relaxing place." When the two pictures are examined, it is clear that the two students want to study the Life Studies course in a clean-air environment, in touch with nature.

Among those who want to study the Life Studies course in an indoor space, Turkan's picture is shown in Figure 3; Barıs' picture is shown in Figure 4; Seda's picture is shown in Figure 5; and Şebnem's picture is shown in Figure 6.

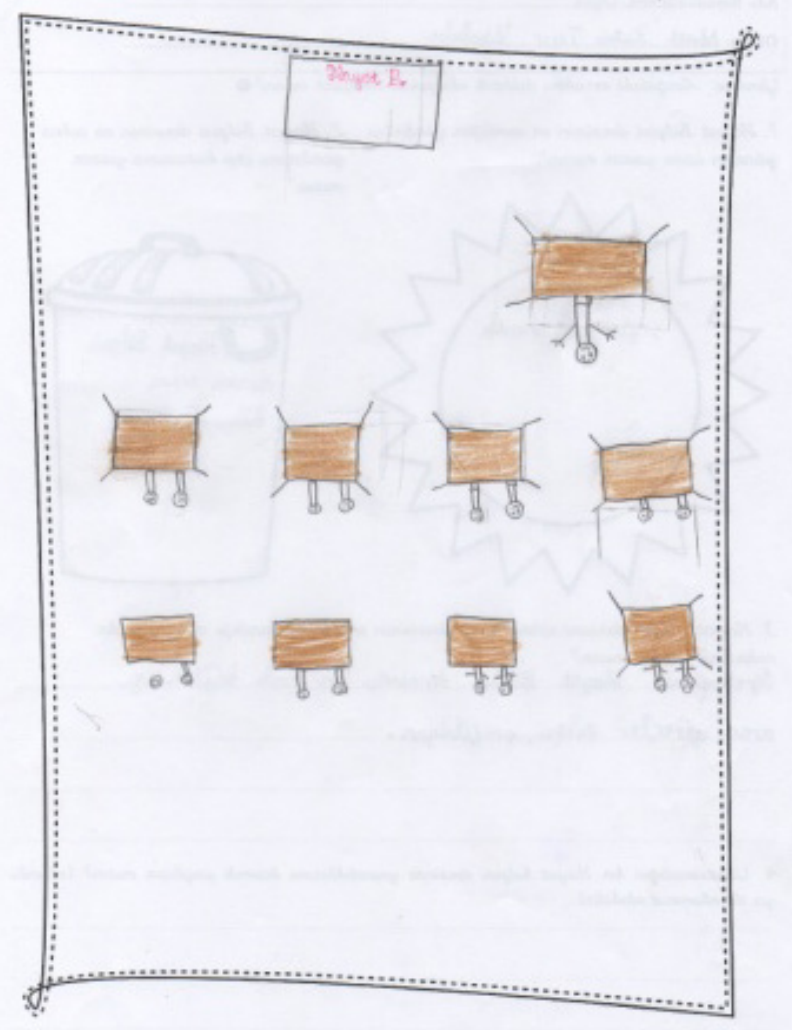

Figure 3. The place in which Turkan wants to study LS 


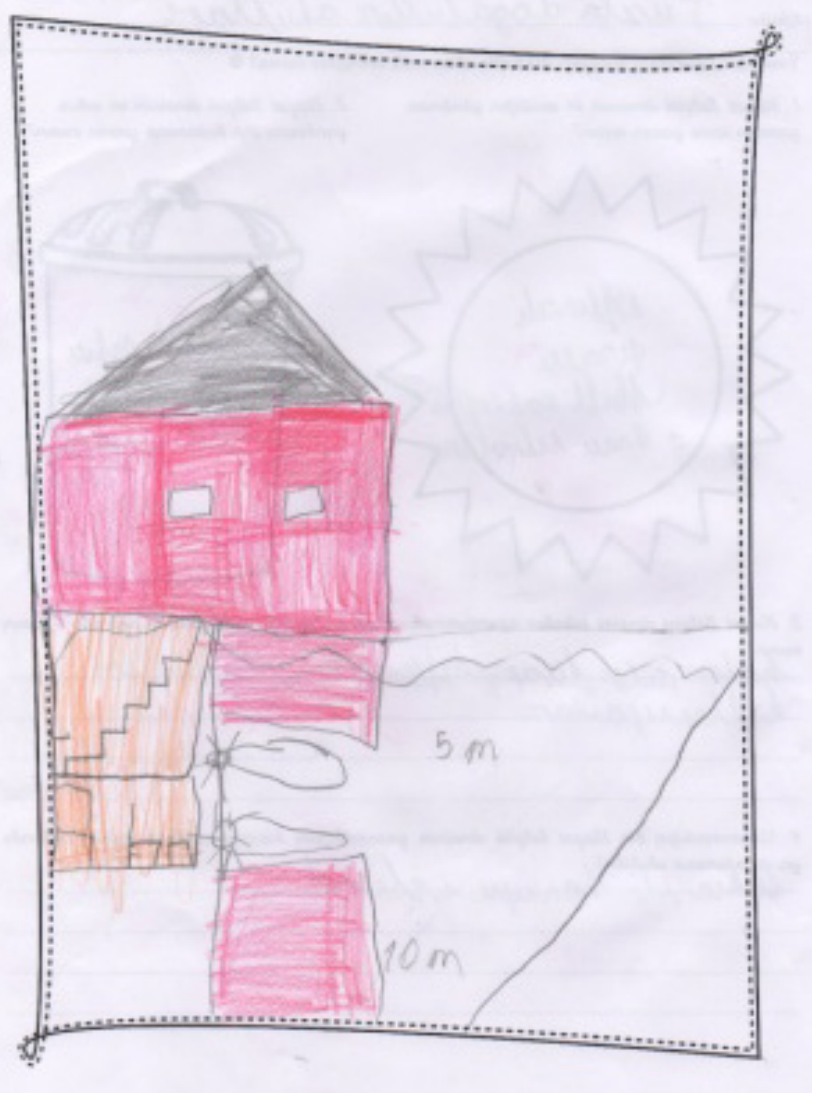

Figure 4. The place in which Barış wants to study LS

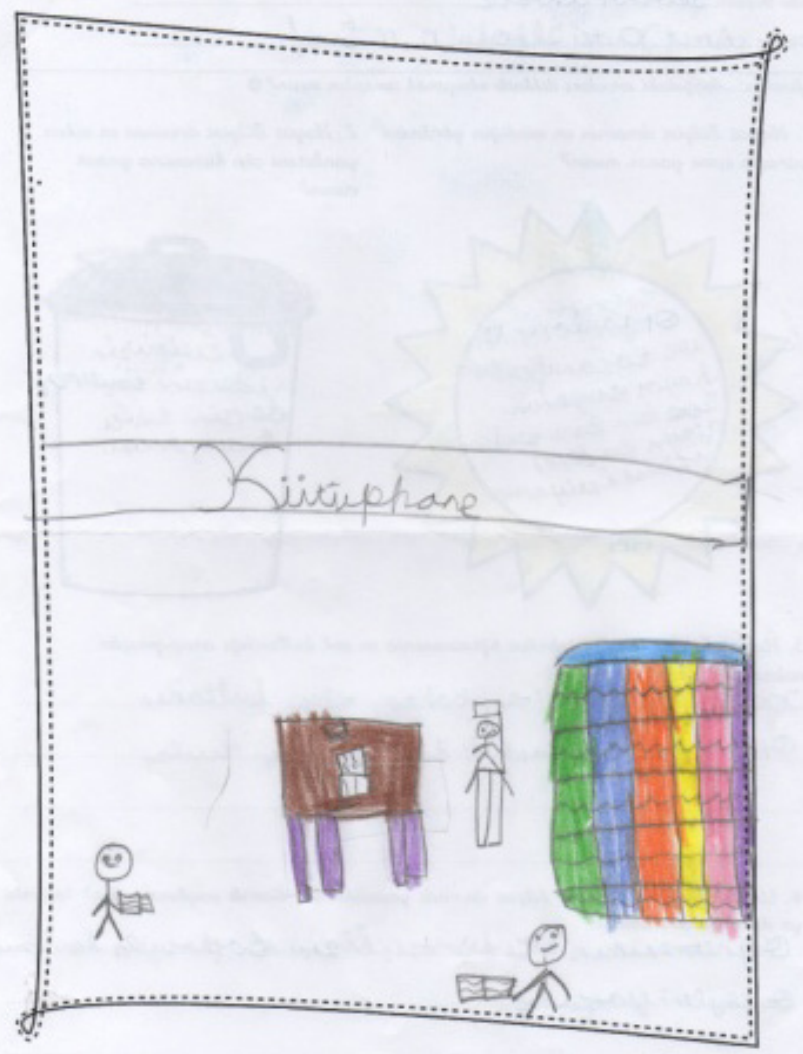

Figure 5. The place in which Seda wants to study LS

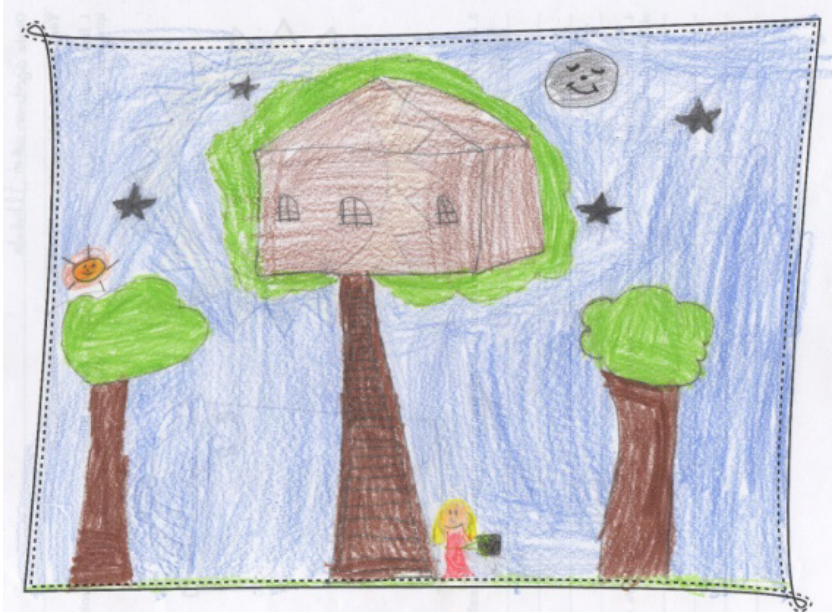

Figure 6. The place in which Şebnem wants to study LS

In the interview with Turkan, who drew the picture in Figure 3, she was asked: "You draw a picture of the place in which you want to study the Life Studies course. Can you explain your picture?" Turkan responded as follows: "In this picture, students and teachers are doing the Life Studies course in the classroom. There are tools and materials we use in the class. For example, we have to be in the classroom to use the projector. I think the best place is the classroom. Our garden is not beautiful anyway; our classroom is more beautiful." Barış, who drew the picture in Figure 4, expressed himself as follows: "Teacher, I drew a school here in the middle of the sea. Because the school is in the middle of the sea, our shuttles have to be submarines. I draw the stairs because my classroom and the library are on the lower floor of the school. The course would be more fun in such a place, and it would easier for us to learn submarine creatures. But if we are going to do a lesson about nature, then we should be able to study in the forest because it's easier to learn by seeing."

Seda, who drew the picture in Figure 5, expressed herself as follows: "I would like to study there because I can find more information in the library. It is both full of information and quiet and calm. You must not talk loudly in libraries. I can learn better in such a quiet environment." Finally, Şebnem, who drew the picture in Figure 6, held the following views: "I would like to do the course in a tree house in the forest because I can learn better in a place with natural life. I would like to study in this tree house and learn the topic "You were also a child." There should be a board in this house, because our teacher can teach us something on a board." Considering Figures 3, 4, 5, and 6, although the students depicted the place to hold the Life Studies course as an indoor space, they emphasized that it should be quiet, in touch with nature, and inside real life.

Bora's picture in Figure 7 could not be placed under either of the two categories; thus, it was evaluated under the category of other. Bora was asked: "You draw a 
picture of the place in which you want to study the Life Studies course. Can you explain us your picture?" He responded as follows: "For example, there will be a truck; desks and chairs will be out inside the truck. It will have windows on its sides. We will be studying while the truck is on the road. According to the topic we are studying, we can go to a city and see that city. For example, if we are talking about fairy chimneys, we can go to Cappadocia. We can observe it not only by looking through the window, but also by visiting outside the truck. While the teacher is telling us the lesson, someone else will use the truck. So, we will both travel and learn."

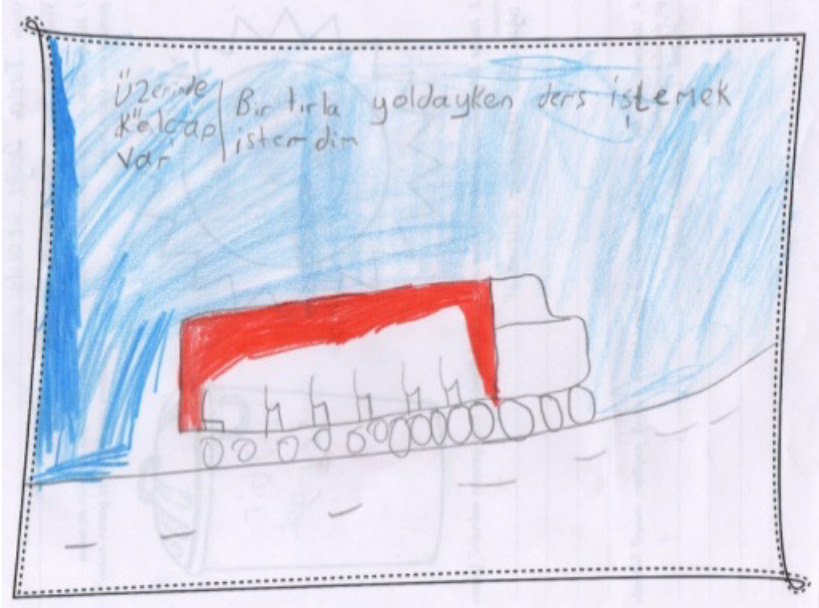

Figure 7. The place in which Bora wants to study LS

Considering Figure 7, it seems that Bora seeks to convey that schools trips should be related to topics, and students can learn better on trips.

\subsection{Results of Students' Perceptions of the Seating Arrangement in the Life Studies Course}

Table 8 shows the frequency and percentage values for the themes and codes determined, based on the analysis of students' pictures, with respect to their perceptions of the seating arrangement in the Life Studies course.

Table 8. Results of Students' Perceptions of the Seating Arrangement in the Life Studies Course

\begin{tabular}{|c|c|c|c|}
\hline Theme & Code & $\boldsymbol{f}$ & $\boldsymbol{\%}$ \\
\hline Not drawn & ---- & 48 & 32.2 \\
\hline \multirow{3}{*}{ Individual } & Individual seating & 40 & 26.9 \\
\cline { 2 - 4 } & On a cushion & 13 & 8.7 \\
\cline { 2 - 4 } & Standing & 22 & 14.8 \\
\hline \multirow{3}{*}{ Group } & Two students per desk & 17 & 11.4 \\
\cline { 2 - 4 } & cluster seating & 5 & 3.3 \\
\cline { 2 - 4 } & U-shape & 4 & 2.7 \\
\hline \multirow{2}{*}{ Total } & $\mathbf{1 4 9}$ & $\mathbf{1 0 0}$ \\
\hline
\end{tabular}

Given the data in Table 8, seven of the student perceptions focus on individual seating arrangement, while 26 focus on group seating arrangement. Figure 8 , Figure 9, and Figure 10 show the pictures of the students interviewed after being selected among those who focused on individual seating arrangement. In the interview with Selma, who drew the picture in Figure 8, she responded to the following question: "You draw a picture of the place in which you want to study the Life Studies course. Can you explain your picture?" She responded as follows: "There are students sitting on cushions, and there is a teacher. So, it's more fun like that; everyone wants it. Also, we feel better because we will be able to relax. I wish we could do something like this." Ahmet, who drew the picture in Figure 9, explained: "Here we go to the forest; we are doing a Life Studies course about plants and trees. We are learning by touching it instead of looking at a tree image. That is, we do practice. It's easier to learn like this. My teacher and friends are also in the picture. But I am on the top of the waterfall because I love to learn by discovering on my own." Finally, Murat, who drew the picture in Figure 10, expressed himself as follows: "This is the Life Studies learning Course. This course is in the middle of Turkey, in Ankara. The teacher is not my teacher. They come from all over Turkey to attend this course; they learn the importance of Life Studies, and they learn important concepts. I am the boy sitting in the back. My friend sitting in the front seat has come from another school. Everyone is sitting alone so that we will not bother each other."

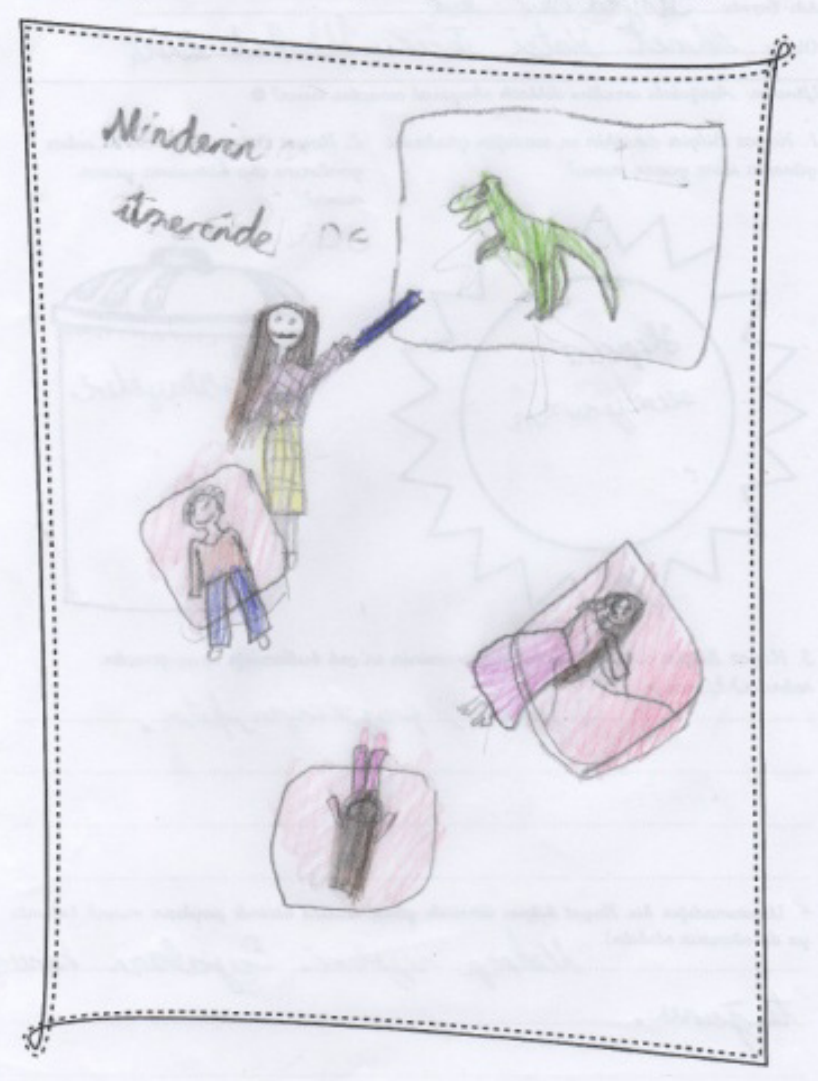

Figure 8. The place in which Selma wants to study LS 


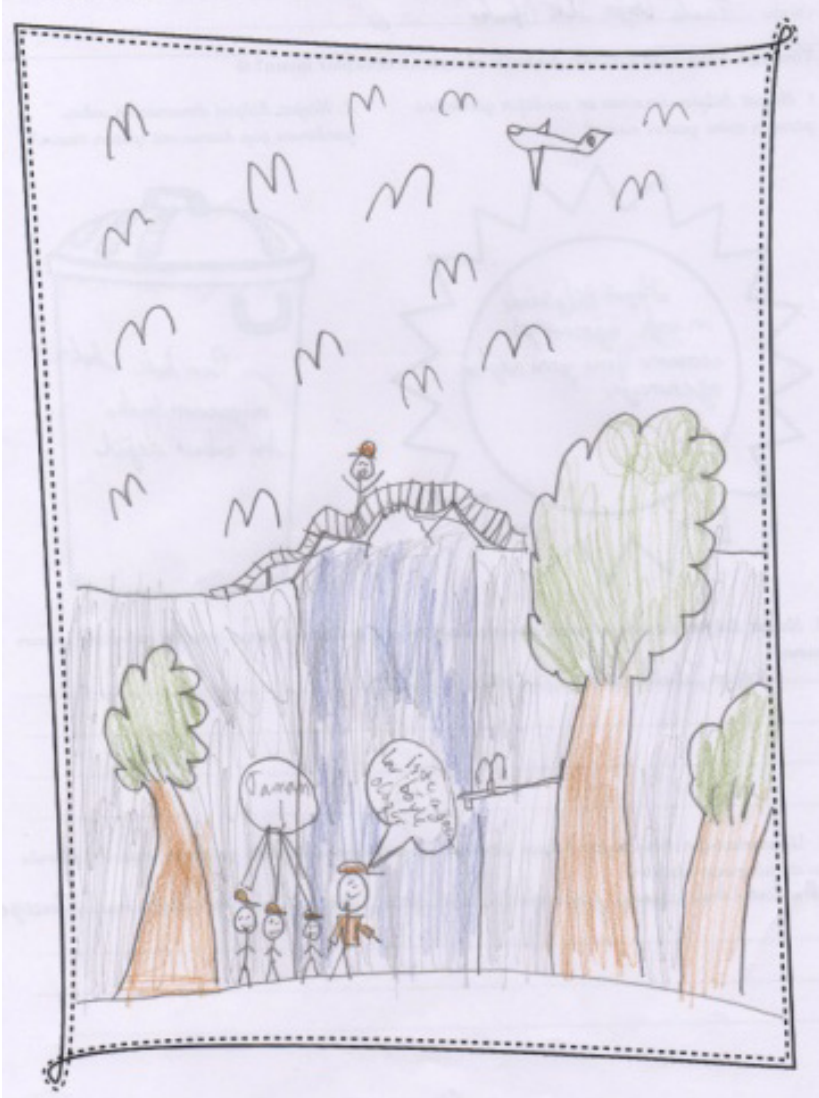

Figure 9. The place in which Ahmet wants to study LS

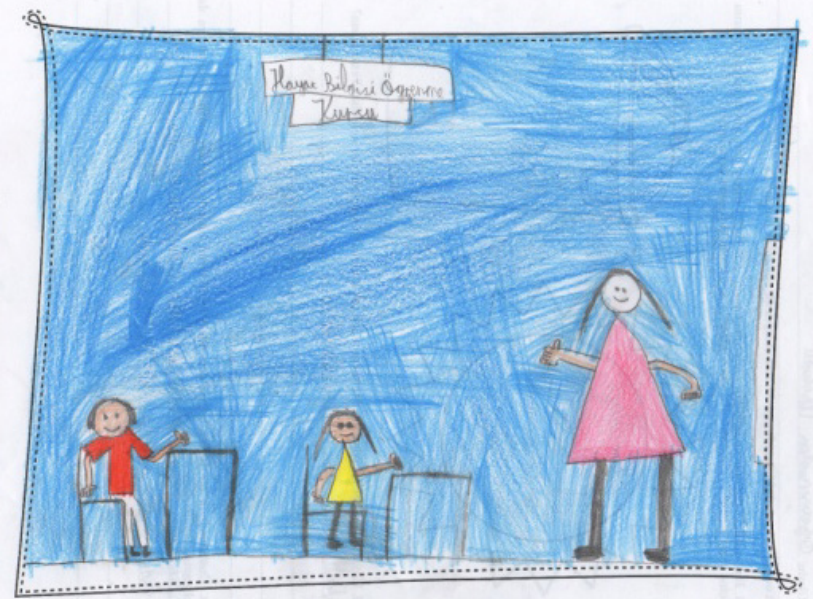

Figure 10. The place in which Murat wants to study LS

Considering Figures 8, 9, and 10, individual seating arrangement was emphasized. These pictures can be interpreted as follows: sitting alone on a cushion facilitates learning in a more comfortable setting, students do not disturb each other while seated individually, and students would like to study and learn in a setting that allows them to discover on their own.

Figure 11, 12 and 13 show pictures of students who focus on group seating arrangement. Serdar, who drew the picture in Figure 11, was asked in the interview: "You draw a picture of the place in which you want to study the Life Studies course. Can you explain your picture?" He responded as follows: "I would like to study in an outdoor space. Having no walls around would be a bit disturbing, but it would be very enjoyable to study in such an environment. It is very enjoyable to sit with a friend I choose, although sometimes it is a problem to sit with another student on a desk. We do not have to change seats constantly when we do group work in the class." Mert, who drew the picture in Figure 12, explained as follows: "In this picture, I wanted to tell you that I would like to do the LS course in the forest, because I think the forest is very nice. It would be great if we could have classes with rabbits. We are doing group work in this class. I drew it just like the group we made in the class. When it is like that, I can see the face of all my group mates. It is very good to sit like that. We put the materials we will use in the middle; everyone can get to them easily." Feyza, who drew the picture in Figure 13, expressed the following: "We are studying the Life Studies course with my classmates. We have paper and pencil in our hands, and our teacher holds a textbook. We are sitting on the ground in the garden. But there are no trees in the garden, only green grass. I also draw the Turkish flag as it is in the school garden. We all sit in such a position that we can see our teacher. So, everybody can see our teacher, and the teacher can see us, too."

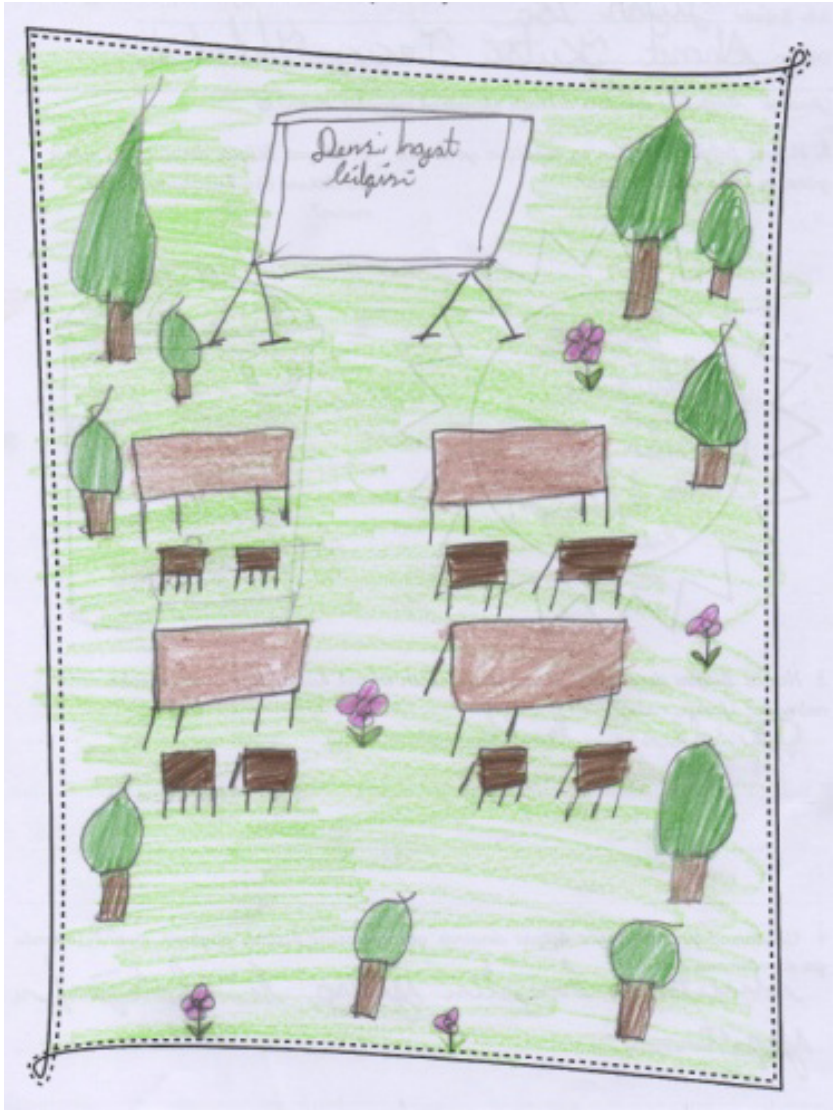

Figure 11. The place in which Serdar wants to study LS 


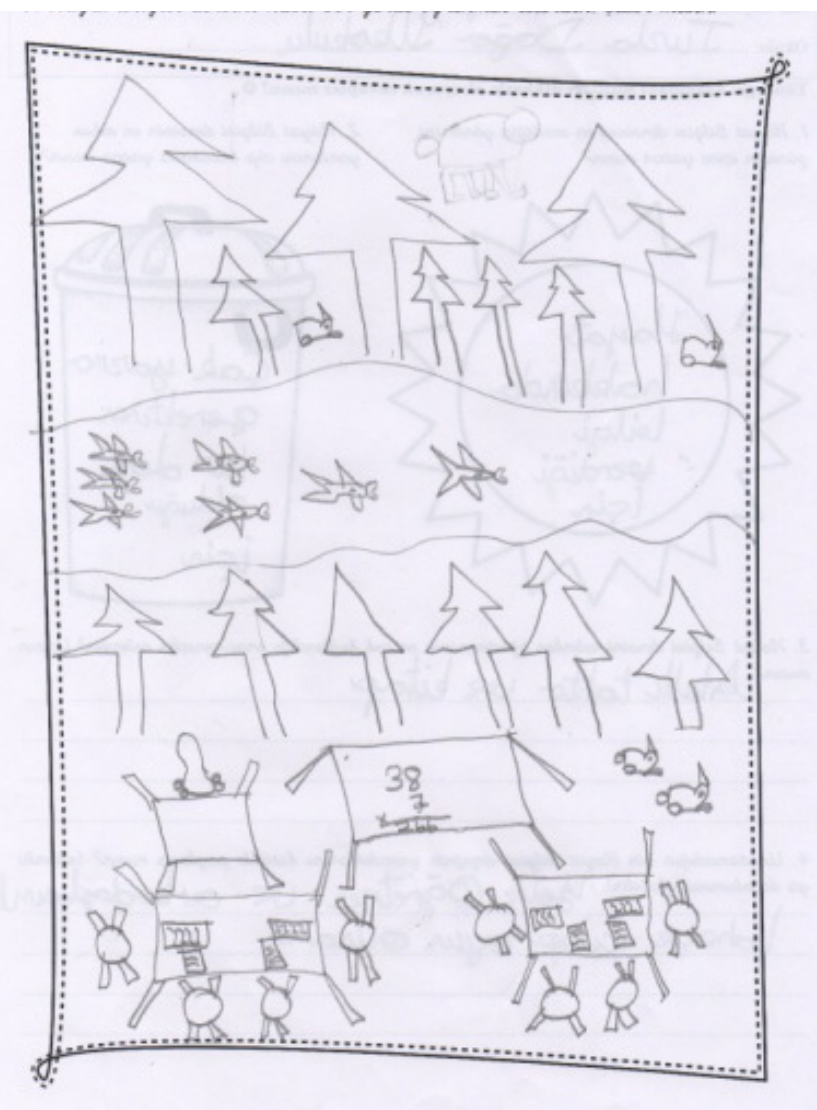

Figure 12. The place in which Mert wants to study LS

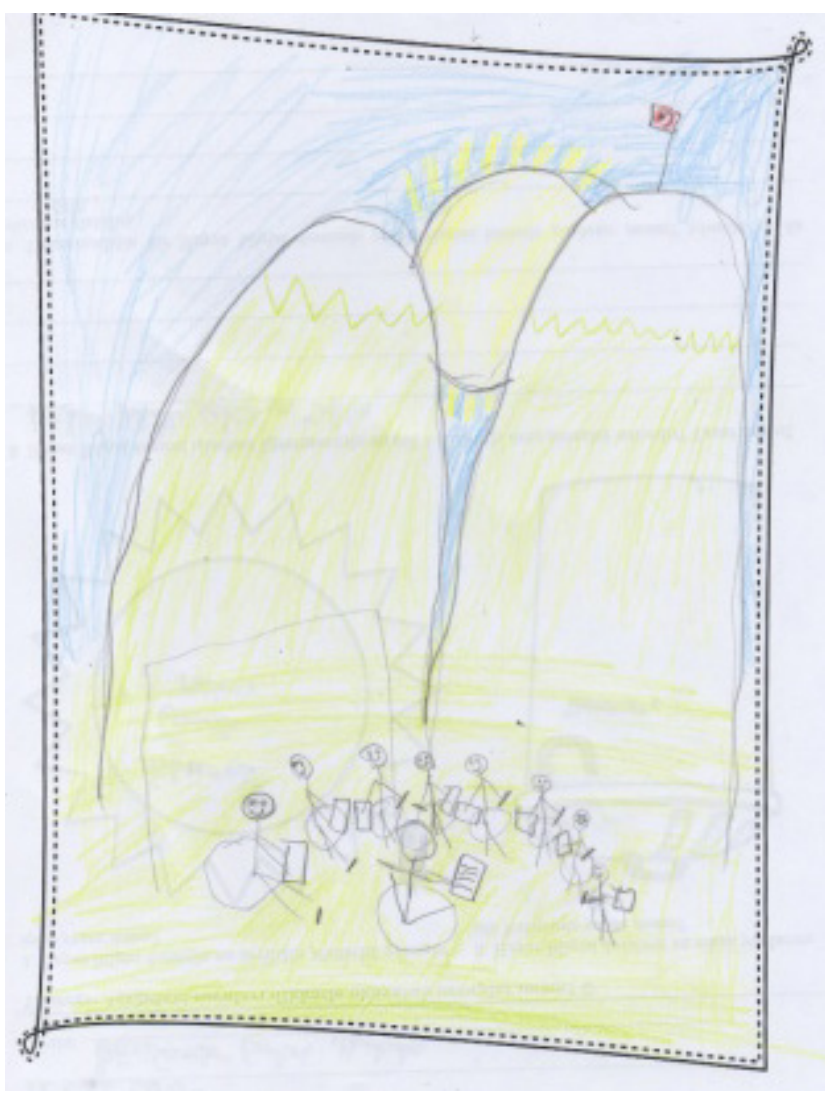

Figure 13. The place in which Feyza wants to study LS
In Figures 11, 12, and 13, group seating arrangement was emphasized. It appears that the children support a grounded group seating arrangement. They were willing to sit in a group and work with a friend they liked, and they demonstrated a preference for the use of materials and the position from which they viewed their teacher.

\section{Discussion and Suggestions}

This research can be regarded as an important study in that it reflects students' perceptions of the Life Studies course. Especially with respect to activities prepared for the new Life Studies Curriculum, which has gradually been implemented nationwide beginning with the 2015-2016 academic year, the research results appear to help teachers gain a fresh perspective on what kinds of activities they should focus on when planning the course.

The literature includes studies on Life Studies courses that focus on teachers' views and the acquisition of basic skills (Öztürk [6]); textbooks and student workbooks (Güven [14]; Karaca \& Ocak [26]); methods and techniques (Aykaç [2]); and the evaluation of curricula (Kazu \& Aslan [27]; Çalışoğlu, Tortum, Erişmiş \& Koçyiğit [28]). These studies seek to reveal the existing situation and to conduct an assessment based on teachers' views. On the contrary, there exists a limited volume of research with students designated as the "subject" of the Life Studies course. This situation may stem from the fact that working with children at such a young age is not preferable. However, several studies have used student pictures to investigate students' views about school (Leitch \& Mitchell [29]), the Internet (Ersoy \& Türkkan [30]), scientist (Kaya, Doğan \& Öcal [31]), environmental and social problems (Ersoy \& Türkkan [32]), and teachers and teacher perceptions (Aykaç [33]). Drawings can also provide valuable visual data about how children see events and facts (Clark [34]; Dockett \& Perry [35]). Accordingly, it appears to be appropriate to consider the views of the study group.

Conducted with 146 elementary school second- and third-grade students, the study addressed five research questions. However, the fourth question, "What are students' experiences with the Life Studies course?", asked the students to write down their experiences. Whether students' experiences were positive or negative was detected through the researchers' analysis and was then categorized accordingly. Hence, "the most boring aspects of the Life Sciences course" and "negative experiences with the Life Sciences course" were evaluated separately. As to the differences between the two questions, the first question was intended to reveal perceptions regarding the course, whereas the second question attempted to ascertain students' experiences.

In this study, which surveyed students, participants identified the most enjoyable aspect of the Life Studies 
course as the methods and techniques used in the class, activities, reading, writing, and painting. Concerning the meanings attributed to the course, students consider Life Studies an enjoyable and easy course that explains life and teaches new information. According to Ögülmüş [36], children tend to do things they like and to be with people they love in order to be happy, while they tend to avoid things and people they dislike.

The unfavorable aspects of the Life Studies course primarily resulted from teachers and materials used. Students' dislikes for the Life Studies course include too much writing, the inability to take a turn to talk, and teachers who keep the class waiting or give clues. Students also reported that they did not like activities and reading stories and they found the course boring because it was easy. Considering the unfavorable aspects of the course in general, it seems that teacher-related problems were emphasized. Öztürk and Baysal [37] found a significant difference between students' level of utilization of teachers and students' attitudes toward Social Studies courses. Thus, teachers have significant duties in fostering positive attitudes toward the Life Studies course.

The most commonly used materials in the Life Studies course include a board marker, textbook, board, smart board, computer, projector, and notebook. The least used materials are an earth model, compass, guide book, and a map of Turkey. Akbaba [38] has noted that the use of visual materials in Social Studies classes stimulates students' interest, and the use of pictures, photographs, cartoons, miniatures, and newspapers render the teaching-learning process richer and more qualified. Considering the students' perceptions in this study, it is remarkable that the use of materials mentioned is insufficient.

In the present study, students' positive experiences with the Life Studies course were grouped into the following categories: active participation in the class, having an enjoyable time, enjoying the course content, and feeling successful. It seems that students' positive experiences primarily stemmed from the methods and techniques used in the class. Hanbaba and Bektaş [39] have argued that the use of the teaching-through-play method in Social Studies classes has a partially positive effect on class attitudes, with students enjoying a pleasant time. Drama activities have also proven to have a positive effect on students' attitudes toward Social Studies courses (Karadağ \& Çalışkan [40]).

In this study, students' negative experiences with the Life Studies course include the following: teacher speaks at all times, always reading funny and sad stories, a lot of writing assignments, and displaying unfavorable behaviors in class. It is remarkable that the Life Studies course was negatively evaluated because the stories were "sad or very funny." Research results have indicated that students want to read books with plenty of pictures and a small number of pages that they can enjoy (Ateş, Çetinkaya \& Yıldırım [41]). When books are printed in different sizes and have interesting designs, it will broaden children's perspective, foster a sense of curiosity and discovery, contribute to their creativity, and promote scientific literacy (Gönen, Katrancı, Uygun \& Uçuş [42]).

In order to learn about students' dreams regarding the place/space to hold the Life Studies course, participants were asked to draw a picture. Based on the analysis of students' pictures, participants most often wanted to study Life Studies in an outdoor space, and even those preferring an indoor space drew the sun, trees, etc. in their pictures. Considering the seating arrangements preferred by students, participants most often emphasized an individual seating arrangement. Based on students' reports, sitting alone on a cushion facilitates learning in a more comfortable setting, and students do not disturb one another while seated individually. Although a small number of students emphasized a group seating arrangement, participants reported that they wanted to sit in a position that allowed them to see their teacher other easily, and that also allowed their teacher to see them easily. Each child represents a different world and a unique perspective that must be explored (Kabapınar [43]). Accordingly, each drawing of dreams about the Life Studies course can be considered as important data source, as each reflects a distinct point of view.

The results of this study are significant in that they reflect students' perceptions of the Life Studies course. In light of the fact that Life Studies is a course that strives to raise happy individuals, the study results may help teachers to create a class setting and a course plan that are more suitable to students' wishes and needs, and may also help students to explore themselves while being taught basic life and social skills.

Consistent with these results, the study offers the following suggestions:

- Design ongoing research by enriching the research data to gain more in-depth knowledge;

- $\quad$ Prepare new and more creative activities by taking into consideration students' interests and wishes and the acquisition of the Life Studies curriculum;

- In order to ensure that student views of Life Studies classes are more positive, reorganize the physical structure of classrooms, using such methods as sight-seeing, drama, and performances more frequently, and more actively using schoolyards and outdoor spaces in teaching and learning processes;

- Organize teacher training activities, and show example cases on how to prepare different activities for Life Studies classes.

Last but not least, the statement "to raise happy individuals" in the Life Studies Curriculum of 2004 was replaced by the statement "to happily prepare students for life" under the section entitled: "Teaching Values in the 
Draft Curriculum of 2017.” These changes are inevitable. Thus, we hope to see arrangements made to help raise happier children in a course such as Life Studies, which seeks to prepare students for life and instructs them in the areas of social, natural and individual lives.

\section{REFERENCES}

[1] Acar, D. 1962 ve 2005 yılları arası Hayat Bilgisi, Türkçe ve Sosyal Bilgiler ders kitaplarında yer alan Atatürk kavramının içerik analizi, MA Thesis, Gazi University, The Institute of Educational Sciences, Ankara, 2006.

[2] Aykaç, N. Hayat Bilgisi Dersi Öğretim Programında Kullanılan Yöntem Ve Tekniklerin Öğretmen Görüşlerine Göre Değerlendirilmesi (Sinop İli Örneği), Kastamonu Eğitim Fakültesi Dergisi, Vol. 19, No. 1, 113-126, 2011.

[3] Belet, D. İlköğretim kurumlarında uygulanan hayat bilgisi programının değerlendirilmesi, MA Thesis, Anadolu University, The Institute of Social Sciences, Eskişehir, 1999.

[4] Binbaşığlu, C. Hayat bilgisi öğretimi Nobel Yayın Dağıtım, Ankara, 2003.

[5] Köken, N. Çocuk ve hayat bilgisi, Ahi Evran Üniversitesi Kırşehir Eğitim Fakültesi Dergisi, Vol. 4, No. 1, 15-27, 2003.

[6] Öztürk, T. Öğrencilerin hayat bilgisi dersi öğretim programındaki temel becerileri kazanmalarına yönelik ögretmen görüşleri. Eğitim ve Bilim, Vol. 40, No. 181, 271-292, 2015.

[7] Sönmez, V. Hayat bilgisi öğretimi ve öğretmen kılavuzu, MEB Yayınları, Istanbul, 1999.

[8] Ministry of National Education. İlkokul hayat bilgisi ögretimi taslak programı (1. 2. ve 3. sinıflar), Talim Terbiye Kurulu, Ankara, 2017.

[9] Demir, M. K. Hayat bilgisi öğretim programının değiştirilmesi gerekçelerine dair öğretmen adayı görüşleri, The Journal of Academic Social Science Studies, No. 47, 157-171, 2016.

[10] Buchanan-Barrow, E. Children's understanding of the school. In Barrett, M., Buchanan-Barrow, E (Eds.), Children's understanding of society. Psychology Press, USA, 2005 .

[11] Bektaş, Ö. Hayat bilgisi öğretimi, MA Thesis, Atatürk University, The Institute of Social Sciences, Erzurum, 2001.

[12] Güngördü, E. İlköğretimde hayat bilgisi ve sosyal bilgiler öğretimi, Nobel Yayın Dağıtım, Ankara, 2001.

[13] Güçlü, N. Hayat bilgisi ders kitabının tasarımı In Küçükahmet, L. (Ed.), Konu alanı ders kitabı inceleme kılavuzu hayat bilgisi 1-3, Nobel Yayın Dağıtım, Ankara, 2001.

[14] Güven, S. İlköğretim hayat bilgisi dersi ders ve öğrenci çalışma kitaplarının öğretmen görüşlerine göre değerlendirilmesi, Eğitim ve Bilim, Vol. 35, No. 156, 84-95, 2010 .
[15] Yel, S. Hayat bilgisi dersinin öğretimi ve içerik In Küçükahmet, L. (Ed.), Konu alanı ders kitabı inceleme kılavuzu hayat bilgisi 1-3, Nobel Yayın Dağıtım, Ankara, 2001.

[16] Yüksel, G. Öğretmenlerin sahip olmaları gereken davranış olarak sosyal beceri, Milli Eğitim Dergisi, No. 150, 2001, Online available form

http://dhgm.meb.gov.tr/yayimlar/dergiler/milli_egitim_derg isi $/ 150 /$ yuksel.htm

[17] Ersoy, F., Fenomenoloji. In Saban, A., Ersoy, A. (Eds.), Eğitimde Nitel Araştırma Desenleri, (pp. 51-105). Anı Yayıncilık, Ankara, 2016.

[18] Halmatov, S. Çocuk resimleri analizi ve psikolojik resim testleri, Pegem Yayıncılık, Ankara, 2016.

[19] Malchiodi, C. A. Çocukların resimlerini anlamak Epsilon Yayıncilık, Istanbul, 2005.

[20] Creswell, J. W. Educational research: Planning, conducting, and evaluating quantitative and qualitative research, Pearson Publications, Boston, 2012.

[21] Yıldırım, A., Şimşek, H. Sosyal bilimlerde nitel araştırma yöntemleri Seçkin Yayıncılık, Ankara, 2013.

[22] Patton, M.Q. How to use qualitative methods in evaluation. California, SAGE Publications, 1997.

[23] Yavuzer, H. Resimleriyle çocukları tanıma, Remzi Kitabevi, Istanbul, 2000.

[24] Corbin, J. M., Strauss, A. C. Basics of qualitative research: Techniques and procedures for developing grounded theory, California, Sage Publication, 2007.

[25] Leonard, M. Children's drawings as a methodological tool: reflections on the eleven plus system in Northern Ireland, Irish Journal of Sociology, Vol. 15, No. 2, 52-66, 2006.

[26] Karaca, N., Ocak, G. Hayat bilgisi ders kitaplarının becerilere uygunluk düzeyinin öğretmen görüşlerine göre değerlendirilmesi (Afyonkarahisar ili örneklemi), Kuramsal Eğitimbilim Dergisi, Vol. 4, No. 1, 108-125, 2011.

[27] Kazu, H., Aslan, S. Birleştirilmiş sınıf öğretmenlerinin hayat bilgisi dersi öğretim programına yönelik görüşlerinin incelenmesi (Nitel bir araştırma), Turkish Studies, Vol. 7, No. 2, 693-706, 2012.

[28] Çalışoğlu, M., Tortum, T., Erişmiş, F., \& Koçyiğit, D. Yeni yapılandırılan 3. Sinıf hayat bilgisi ve fen bilimleri derslerine yönelik öğretmen görüşleri, Uluslararası Multidisipliner Akademik Araştırmalar Dergisi,Vol. 2, No. $2,1-11,2015$

[29] Leitch, R., Mitchell, S. Caged birds and cloning machines: How student imagery 'speaks' to us about cultures of schooling and student participation. Improving Schools, Vol. 10, No. 1, 53-71, 2007.

[30] Ersoy, A., Türkkan, B. İlköğretim Öğrencilerinin Resimlerinde İnternet Algıs1, İlköğretim Online Dergisi, Vol. 8, No. 1, 57-73, 2009.

[31] Kaya, O. N., Doğan, A., Öcal, E. Turkish elementary school students' images of scientists, Eurasion Journal of Educational Research, No. 32, 83-100, 2008. 
[32] Ersoy, A. F., Türkkan, B. İlköğretim öğrencilerinin çizdikleri karikatürlere yansıttıkları sosyal ve çevresel sorunların incelenmesi, Eğitim ve Bilim, Vol. 35, No. 156, 96-109, 2010.

[33] Aykaç, N. İlköğretim öğrencilerinin resimlerinde öğretmen ve öğrenme süreci algısı, Eğitim ve Bilim, Vol. 37, No. 164, 298-315, 2012.

[34] Clark, A. Listening to and involving young children: A review of research and practice. In A. Clark, A. T. Kjörholt, P. Moss (Eds.), Beyond listening: Children's perspectives on early childhood services (pp. 490-505). Policy Press, Bristol, 2005.

[35] Dockett, S., Perry, B. Children's drawings: Experiences and expectations of school, International Journal of Equity and Innovation in Early Childhood, Vol. 3, No. 2, 77-89, 2005.

[36] Öğülmüş, S. İlköğretim hayat bilgisi öğretimi ve öğretmen el kitab1, PegemA Yayıncılık, Ankara, 2009.

[37] Öztürk, C., Baysal, Z.N. İlköğretim 4-5. sınıf öğrencilerinin sosyal bilgiler dersine yönelik tutumu, Pamukkale Üniversitesi Eğitim Fakültesi Dergisi, Vol. 6, No. 6, 11-20, 1999.

[38] Akbaba, B. Photograph usage in history education. The
Turkish Online Journal of Educational Technology, Vol. No. 3, 39-47, 2009.

[39] Hanbaba, L., Bektaş, M. Oyunla öğretim yönteminin hayat bilgisi dersi başarıs1 ve tutumuna etkisi, Abant İzzet Baysal Üniversitesi Eğitim Fakültesi Dergisi, Vol. 12, No. 1, $115-128,2012$.

[40] Karadağ, E., Çalışkan, N. İlköğretim birinci kademesi öğrencilerinin drama yöntemine karşı tutumlarının değerlendirilmesi, Pamukkale Üniversitesi Eğitim Fakültesi Dergisi, Vol. 19, No. 19, 45-57, 2006.

[41] Ateş, S., Çetinkaya, Ç., Yıldırım, K. Öğretmen, ebeveyn ve öğrencilerin görüşlerine göre ilköğretim öğrencilerinin okuma çevreleri, International Online Journal of Educational Sciences, Vol. 4, No.2, 374-394, 2012.

[42] Gönen, M., Katrancı, M., Uygun, M., Uçuş, Ş. İlköğretim birinci kademe öğrencilerine yönelik çocuk kitaplarının, içerik, resimleme ve fiziksel özellikleri açısından incelenmesi, Eğitim ve Bilim, Vol. 36, No. 160, 250-265, 2011.

[43] Kabapınar, Y. İlköğretimdeki hayat bilgisi ve sosyal bilgiler derslerinde kullanılacak bir öğretim etkinliği olarak resim çizimi yoluyla empatik Marmara Üniversitesi Eğitim Bilimleri Dergisi, Vol. 20, No. 20, 85-100, 2004. 